\title{
Efficacy \& Safety of Oral Ivermectin and Topical Permethrin in the Treatment of Scabies
}

\author{
Akhter M', Bhuiyan I' ${ }^{2}$, Hossain MS ${ }^{3}$, Khan $\mathbf{Z H}^{4}$, Akhter $\mathbf{M}^{5}$, Mumtaz F
}

Conflict of Interest: None

Received: 21.03.2019

Accepted: 27.08 .2019

www.banglajol.info/index.php/JSSMC

\section{Key Words:}

Ivermectin, permethrin, scabies

\begin{abstract}
:
Background: Scabies is one of the most common skin diseases in our country. It is caused by the mite Sarcoptes scabiei var hominis, which is an ecto-parasite infesting the epidermis. Scabies is highly contagious. Prevalence is high in congested or densely populated areas. Individuals with close contact with an affected person should be treated with scabicidal which is available in both oral and topical formulations. The only oral but highly effective scabicidal known to date is Ivermectin. Amongst topical preparations, Permethrin $5 \%$ cream is the treatment of choice.
\end{abstract}

Objective: To evaluate the efficacy \& safety of oral Ivermectin compared to topical Permethrin in the treatment of scabies.

Methodology: This prospective, non-randomized study was conducted at the out-patient department of Dermatology and Venereology of Shaheed Suhrawardy Medical College \& Hospital over a period of 6 months, from August 2016 to January 2017. The study population consisted of one hundred patients having scabies, enrolled according to inclusion criteria. They were divided into two groups. Group A was subjected to oral Ivermectin and the Group $B$ to Permethrin 5\% cream. Patient were followed up on day 7, 14 and assessed for the efficacy and safety.

Result: The mean scoring with SD in Group A and Group B were $8.26 \pm 2.22$ and $7.59 \pm$ 2.01 respectively at the time of observation. The difference between the mean score of the two group is not significant $(p=0.117)$ The mean scoring with $S D$ in group A and group $B$ were $4.54 \pm 2.05$ and $1.64 \pm 1.84$ respectively at $7^{\text {th }}$ days. The difference between the mean score of the two group is significant $(p<0.001)$. The mean scoring with $S D$ in group A and group $B$ were $2.68 \pm 2.35$ and $.36 \pm 1.10$ respectively at $14^{\text {th }}$ day difference between the mean score of the group is significant $(p<0.001)$.

Conclusion: Topical application of Permethrin 5\% cream is more effective and safer than oral Ivermectin in the treatment of scabies.

[J Shaheed Suhrawardy Med Coll 2019; 11(2): 91-95] DOI: https://doi.org/10.3329/jssmc.v11i2.48956
1. Dr. Mohsena Akhter, Assistant Professor, Department of Dermatology and Venereology, ZH Sikder Medical College \& Hospital

2. Dr. Ishrat Bhuiyan, Associate Professor, Department of Dermatology and Venereology, Shaheed Suhrawardy Medical College and Hospital, Dhaka

3. Dr. Md. Shahadat Hossain, Professor, Department of Dermatology and Venereology, Shaheed Suhrawardy Medical College Hospital

4. Dr. Zulfiqer Hossain Khan ,Professor, Department of Dermatology and Venereology, Mugda Medical College \& Hospital

5. Dr. Mahfuza Akhter, Associate Professor, Department of Dermatology and Venereology, Shaheed Suhrawardy Medical College and Hospital

6. Dr. Fahima Mumtaz, Post-graduate trainee, Department of Dermatology and Venereology, Shaheed Suhrawardy Medical College \& Hospital

Correspondence to: Dr. Ishrat Bhuiyan, Associate Professor, Department of Dermatology and VD, Shaheed Suhrawardy Medical College. Mobile: 01711822551, E-mail: ishratskin@yahoo.com

\section{Introduction:}

Human infestation by Sarcoptes scabiei var hominis, an obligate human ecto-parasite causes scabies. Scabies affects all races and social classes worldwide, but accurate figures of its prevalence are difficult to obtain. Incidence of scabies is quite high in India, Bangladesh and Pakistan. In Bangladesh, out of total population having skin diseases, $80 \%$ of are suffering from scabies. ${ }^{1}$ In a community based cross-sectional study, scabies was found in the second position among the infectious skin diseases in a rural area of Bangladesh. ${ }^{2}$

Scabies is usually transmitted by close physical contact, such as prolonged hand-holding or sharing of bed. ${ }^{3}$ Itching is usually the most obvious manifestation of scabies. It is generally worst at night and when the patient is warm. 
The onset occurs 3-4 weeks after the infection is acquired, and coincides with a widespread eruption of inflammatory papules. The pathognomonic lesions of scabies are burrows. Burrows occur on the wrists, borders of hands, sides of fingers and the finger web spaces, feet, particularly the instep and, in males, on the genitalia. They are often present on the palms and soles of young children and the elderly. 4

There have been many suggested remedies for scabies including topical sulphar, 5\% permethrin, benzyl benzoate, malathion, lindane, crotamiton, Monosulfiram and topical and systemic Ivermectin. The choice of therapy is determined not only by efficacy and potential toxicity, but also by considerations such as cost, ease of application, presence of secondary eczematization and age of the patient. $^{5}$

Permethrin 5\% cream is an effective scabicide. At present, it is the topical treatment of choice ${ }^{5}$. Permethrin is a synthetic derivative of the insecticide pyrethrum and function as a neurotoxin to mites and has low toxicity to human.

The only oral but highly effective scabicidal known to date is Ivermectin. ${ }^{6}$ A single dose of $200 \mathrm{ig} / \mathrm{kg}$ body weights will be effective in many cases of ordinary scabies. Higher cure rates are obtained with two doses separated by an interval of a week ${ }^{5}$. It is effective, inexpensive and easy to administer. ${ }^{5}$

\section{Materials and Methods}

The study was conducted on 100 patients having scabies at the out-patient department of Dermatology and Venereology at Shaheed Suhrawardy Medical College Hospital, Dhaka during a period of 6 months, from August 2016 to January 2017, out of which 50 patients were treated with topical Permethrin and 50 patients with oral Ivermectin.

A purposive sampling was carried out. All the patients were diagnosed clinically and allocated into two random groups, Group A and Group B. All the patients had given informed written consent.

Pregnant and lactating women, patients with immunodeficiency or severe systemic disease, with heavily crusted or nodular lesions, secondary infection or eczematization, coexisting dermatological disease and with known hypersensitivity to the trial drugs were excluded from the study

A total of 100 patients with scabies were enrolled in the study. They were randomized into two groups. Group A
Ivermectin $(n=50)$ and Group B Permethrin $(n=50)$. All patients completed 2 weeks study period were reviewed after $7^{\text {th }}$ day and $14^{\text {th }}$ day.

Outcome measures were assessed at baseline and at $7^{\text {th }}$ day and $14^{\text {th }}$ day interval.

\section{Results and Observation:}

The mean scoring with SD in Group A and Group B were $8.26 \pm 2.22$ and $7.59 \pm 2.01$ respectively at the time of observation. The difference between the mean score of the two group is not significant $(p=0.117)$ The mean scoring with SD in group A and group B were $4.54 \pm 2.05$ and $1.64 \pm 1.84$ respectively at $7^{\text {th }}$ days. The difference between the mean score of the two group is significant $(\mathrm{p}<0.001)$. The mean scoring with SD in group A and group $B$ were $2.68 \pm 2.35$ and $.36 \pm 1.10$ respectively at $14^{\text {th }}$ day difference between the mean score of the group is significant $(\mathrm{p}<0.001)$.

Table-I

\begin{tabular}{lccc}
\multicolumn{4}{c}{ Distribution of patients according to sex: } \\
Sex & Group-A & Group-B & $\mathrm{p}$ \\
& $\begin{array}{c}\text { Ivermectin } \\
(\mathrm{n}=50)\end{array}$ & $\begin{array}{c}\text { Permethrin } \\
(\mathrm{n}=50)\end{array}$ & value \\
& No. $(\%)$ & No. $(\%)$ & \\
\hline Male & $27(54.0)$ & $26(52.0)$ & $0.841^{\mathrm{ns}}$ \\
Female & $23(46.0)$ & $24(48.0)$ & \\
\hline Total & $50(100.0)$ & $50(100.0)$ & \\
\hline
\end{tabular}

Chi-square test was done to measure the level of significance, $\mathrm{ns}=$ not significant. Figure within parentheses indicated in percentage

Table-II

Distribution of patients according to age group

\begin{tabular}{lccc}
\hline Age & Group-A & Group-B & $\begin{array}{c}\text { P } \\
\text { (in years) }\end{array}$ \\
& $\begin{array}{c}\text { Ivermectin } \\
(\mathrm{n}=50)\end{array}$ & $\begin{array}{c}\text { Permethrin } \\
(\mathrm{n}=50)\end{array}$ & value \\
& No. $(\%)$ & No. $(\%)$ & \\
\hline $13-22$ & $06(12.0)$ & $12(24.0)$ & \\
$23-32$ & $13(26.0)$ & $14(28.0)$ & \\
$33-42$ & $15(30.0)$ & $11(22.0)$ & \\
$43-52$ & $10(20.0)$ & $08(16.0)$ & \\
$>52$ & $06(12.0)$ & $05(10.0)$ & \\
\hline Total & $50(100.0)$ & $50(100.0)$ & \\
Mean \pm SD & $37.86 \pm 12.81$ & $34.28 \pm 12.74$ & $0.156^{\mathrm{ns}}$ \\
\hline
\end{tabular}




\section{Table-III}

\begin{tabular}{lccc}
\multicolumn{4}{c}{$\begin{array}{c}\text { Distribution of patients according to site of } \\
\text { involvement. }\end{array}$} \\
$\begin{array}{lccc}\text { Site of } \\
\text { involvement }\end{array}$ & $\begin{array}{c}\text { Group-A } \\
\text { Ivermectin } \\
(\mathrm{n}=50)\end{array}$ & $\begin{array}{c}\text { Group-B } \\
\text { Permethrin } \\
(\mathrm{n}=50)\end{array}$ & $\begin{array}{c}\mathrm{p} \\
\text { value }\end{array}$ \\
\hline No. $(\%)$ & No. $(\%)$ & \\
\hline Finger webs & $45(90.0)$ & $47(94.0)$ & $0.714^{\mathrm{ns}}$ \\
Werist & $48(96.0)$ & $46(92.0)$ & $0.677^{\mathrm{ns}}$ \\
Genitalias & $48(96.0)$ & $49(98.0)$ & $1.000^{\mathrm{ns}}$ \\
Areola & $23(46.0)$ & $24(48.0)$ & \\
Axillae & $35(70.0)$ & $33(66.0)$ & \\
\hline
\end{tabular}

*Chi-square test was done to measure the level of significance

\section{Table-IV}

Distribution of patients according to clinical findings of integumentary system.

\begin{tabular}{lccc}
$\begin{array}{l}\text { Clinical findings } \\
\text { of integumentary } \\
\text { system }\end{array}$ & $\begin{array}{c}\text { Group-A } \\
\text { Ivermectin } \\
(\mathrm{n}=50) \\
\text { No. }(\%)\end{array}$ & $\begin{array}{c}\text { Group-B } \\
\text { Permethrin } \\
(\mathrm{n}=50)\end{array}$ & $\begin{array}{c}\mathrm{p} \\
\text { value }\end{array}$ \\
\hline Erythematous papules & $47(94.0)$ & $49(98.0)$ & $0.617^{\text {ns }}$ \\
Excoriation & $44(88.0)$ & $42(84.0)$ & $0.564^{\text {ns }}$ \\
Burrow & $12(24.0)$ & $15(30.0)$ & $0.499^{\text {ns }}$ \\
Nocturnal pruritus & $50(100.0)$ & $50(100.0)$ & $1.000^{\text {ns }}$ \\
\hline
\end{tabular}

Table 4 shows the distribution of patients according to clinical finding of integumentary system. In group A, Erythematous papules were present in 47 cases, Excoriation was present in 44 cases, Burrow was present in 12, and Noctu Excoriation was present in 42 cases, Burrow was present in 15 cases, and Nocturnal pruritis was present in 50 cases.

\section{Table-V}

Efficacy of Ivermectin \& Permethrin at $1^{\text {st }} \& 2^{\text {nd }}$ week $(n=100)$ after treatment according to scoring.

\begin{tabular}{lccc} 
Efficacy & $\begin{array}{c}\text { Group-A } \\
\text { Ivermectin } \\
(\mathrm{n}=50) \\
\text { No. }(\%)\end{array}$ & $\begin{array}{c}\text { Group-B } \\
\text { Permethrin } \\
(\mathrm{n}=50)\end{array}$ & $\begin{array}{c}\mathrm{p} \\
\text { value }\end{array}$ \\
\hline Base line & $(\%)$ & \\
$7^{\text {th }}$ Days & $8.26 \pm 2.22$ & $7.59 \pm 2.01$ & $0.117^{\text {ns }}$ \\
$14^{\text {th }}$ Days & $4.54 \pm 2.05$ & $1.64 \pm 1.84$ & $<0.001^{\mathrm{s}}$ \\
& $2.68 \pm 2.35$ & $0.36 \pm 1.10$ & $<0.001^{\mathrm{s}}$
\end{tabular}

Table 5 shows the distribution of patients according to scoring. The mean scoring with SD in group A and group B were $8.26 \pm 2.22$ and $7.59 \pm 2.01$ respectively at the time of observation. The difference between the mean score of the two group is not significant $(p=0.117)$ The mean scoring with SD in group A and group B were 4.54 \pm 2.05 and $1.64 \pm 1.84$ respectively at $7^{\text {th }}$ days. The difference between the mean score of the two group is significant $(\mathrm{p}<0.001)$. The mean scoring with $\mathrm{SD}$ in group $A$ and group B were $2.68 \pm 2.35$ and $.36 \pm 1.10$ respectively at $14^{\text {th }}$ day difference between the mean score of the group is significant $(\mathrm{p}<0.001)$.

\section{Table-VI}

Adverse Effects of Ivermectin \& Permethrin

\begin{tabular}{lccc} 
Adverse effect & $\begin{array}{c}\text { Group-A } \\
\text { Ivermectin } \\
(\mathrm{n}=50) \\
\text { No. }(\%)\end{array}$ & $\begin{array}{c}\text { Group-B } \\
\text { Permethrin } \\
(\mathrm{n}=50) \\
\text { No. }(\%)\end{array}$ & $\begin{array}{c}\mathrm{p} \\
\text { value }\end{array}$ \\
\hline Nausea & $2(4.0)$ & 0 \\
Vomiting & $1(2.0)$ & 0 \\
Headache & $1(2.0)$ & 0 \\
Pruritis & 0 & $1(2.0)$ \\
Burning & 0 & $2(4.0)$
\end{tabular}

Total

\section{Discussion:}

Scabies is one of the most common infectious diseases in our country. In this study, we evaluated the efficacy \& safety of oral Ivermectin and topical Permethrin in the treatment of scabies. Hundred patients diagnosed of scabies on history and examination was recruited as per inclusion criteria. They were divided by using random number table into group A and group B. Oral Ivermectin were given to group A in a single dose of $200 \mu \mathrm{g} / \mathrm{kg}$ body weight. Group B were given single application of topical Permethrin 5\% cream at night on whole body for 12 hours. Patients were followed up on day 7, 14 and assessed for the efficacy and safety. In the present study male patients were predominant than female in group A and B. In group Amale was 27 (56.7\%) and female was 23 (43.3\%) cases respectively. In group B male was $26(53.3 \%)$ and female was $24(46.7 \%)$ cases respectively. The difference between these two group was not statistically significant $(\mathrm{p}=0.795)$. Similar results were found in a study that overall males are more affected by scabies than females. ${ }^{7}$

According to age majority of the patients were in both groups were from 13-22 to 33-42 years in this study. The 
difference between the age group was not statistically significant $(\mathrm{P}=0.156)$. In general, prevalence of scabies is more in children \& young adult but it can affect all ages. ${ }^{1,7}$

In the study shows that the most common site was the wrist and genitalias 48 (96.0\%) followed by peri-umbilical region 47 (94.0\%), finger web 45 (90.0\%) lower on axillae35 (70.0\%) and areola $23(46.0 \%)$. In group B shows that the most common site wasgenitalias49 $(98.0 \%)$ followed by finger web $47(94.0 \%)$, wrist $46(92.0 \%)$, peri-umbilical region $45(90.0 \%)$, axillae33 $(66.0 \%)$ and areola $24(48.0 \%)$. The differences among the site of involvement of two groups were not significant. Almost similar results were found in a study that the most common site was the genitalia (98\%) followed by wrist $(96 \%)$ then peri-umbilical region(94\%), and web space(94\%) lower on axilla (70\%) and areola (48\%). ${ }^{8}$

Nocturnal pruritus was the most common clinical findings of integumentary system followed by erythematous papules, excoriations and burrows. There is no significant difference between the two groups in clinical features.

The cure rate was more in case of single application of topical Permethrin than single oral Ivermectin at $1^{\text {st }}$ week, which was significant $(\mathrm{p}=<0.001)$. At $2^{\text {nd }}$ week topical Permethrin has more cure rate than oral Ivermectin\& it was also significant $(\mathrm{p}=<0.001)$. According to Aisha Mushtaq et al. topical Permethrin is used nowadays for being safer and more effective than the previously used other drugs. ${ }^{9}$

The scoring of follow up and observation shows that the outcome of patients with topical Permethrin was better than the oral Ivermectin. Some previous study documented that single oral Ivermectin provide a cure rate of $70 \%$ whereas topical Permethrin was associated with $98.0 \%$ cure rate at $2^{\text {nd }}$ week of treatment. According to Reena Sharma, Archana Singal, both Permethrin and Ivermectin in both single and two dose regimen are equally efficacious and well tolerated in scabies. ${ }^{10}$ Usha and Nair have shown efficacy of Ivermectin $200 \mu \mathrm{g} / \mathrm{kg}$ to be equivalent to topical $5 \%$ Permethrin ${ }^{11}$.According to Munazza S, Lamees MM, $\mathrm{M}$ Jahangir there is no significant difference regarding efficacy of topical Permethrin and oral Ivermectin when used in treatment of scabies. ${ }^{12}$ Ivermectin is known to have limited ovicidal activity. So that single oral dose is not appropriate for the treatment. On the other hand, Permethrin have ovicidalproperty, So single application may be appropriate ${ }^{13}$.
In the present study there was no clinically significant difference in nature, frequency, of severity of adverse events between the two treatment groups, as reported in earlier studies. ${ }^{13}$

\section{Conclusion}

In conclusion, our study demonstrated that administration of single application of topical Permethrin was an effective and safe treatment for the treatment of scabies. Treatment with Permethrin has the benefits of rapid resolution of skin lesions and itching compared to oral Ivermectin.

\section{Recommendations:}

Following recommendations are made based on the study findings:

- This study consists of small number of patients\& shorter durations; it emphasizes the fact that further evaluation of the role of oral Ivermectin and topical Permethrin in the treatment of scabies in larger number of patients with longer duration will provide better clarification.

- More follow up should be done to evaluate the better outcome of the patients.

- Longitudinal studies (Cohort study) with larger samples can evaluate the effective and long term outcome for the patients.

\section{Limitation of the study:}

In our country, over-the-counter drugs are available. Many patients had to be withdrawn from the study because they used over-the-counter drugs in case of Ivermectin group for immediate relief.

\section{References:}

1. Islam AKMS, Wadud MA, Skin disease in a rural area of Bangladesh. Bangladesh J dermatol Venereal Leprol 1999;16(2):36-9.

2. Bangladesh Bureau of Statistics. Statistical pocket book of Bangladesh 1998.June1999.Page 351 \& 364. Munazza S, Lamees MM, M Jahangir. A Comparison of efficacy of single topical permethrin and single oral ivermectin in the treatment of scabies. J Pak Assoc Dermatol 2012; 22:45-49.

3. Narendra P Bachewar, Vijay R Thawaniet al. Comparison of safety, efficacy and cost effectiveness of benzyl benzoate, permethrin and ivermectin in patients of scabies. Indian $J$ Dermatol 2009;41: 9-145.

4. Tony Burns, Stephen, Neil Cox, Christopher(Editors):Rook's Text book of Dermatology, Disease caused by Arthropods and other Noxious Animals, Vol-2. ${ }^{\text {th }}$ edition, Wiley-Black Well;2010: 383642. Klaus, Lowell A, Stephen, BarbaraAmy, David (editors) In:Fitzpatrick's Dermatology in General Medicine, Infestations, Stings and Bites, Vol -2, ${ }^{7 \mathrm{TH}}$ edition, McGraw Hill;2008: 20292031. 
5. Klaus, Lowell A, Stephen, Barbara Amy, David (editors) In : Fitzpatrick's Dermatology in General Medicine, Infestations, Stings and Bites, Vol -2, ${ }^{7 \mathrm{TH}}$ edition, McGraw Hill;2008: 20292031

6. Hossain Z M, Miah M A, Ullah M S, Elahi N. A comparative study of oral ivermectin and topical permethrin cream in the treatment of scabies. Bangladesh J dermatol Venereal Leprol 2007;24(2):35-8.

7. http://www.who.int/lymphatic_filariasis/epidemiology/scabies/en/

8. Reena Sharma, Archana Singal. Topical permethrin and oral Ivermectin in the management of scabies: A prospective, randomized, double blind, controlled study. Indian J Dermatol 2011; 77:581-86.
9. Usha V. Nair TG.A comparative study of oral ivermectin and topical permethrin cream in the treatment of scabies. J Am Acad Dermatol 2000;42:236-40.

10. Islam SMN, Begum R, Islam T. Socio-demographic characteristics of scabies patients attending skin \& venereal disease outpatient department of Khulna Medical College Hospital. Bangladesh J dermatol Venereal Leprol 2003;20(1): $16-8$.

11. UshaV. Nair TG.A comparative study of oral ivermectin and topical permethrin cream in the treatment of scabies. J Am Acad Dermatol 2000; 42:236-40. 